Johana WILD, Andreas WILD, Constantin ARDELEANU

\title{
JURNALUL CĂLĂTORIEI LUI ALEXANDRU LAPEDATU SPRE PARIS (DECEMBRIE 1918), PENTRU PARTICIPAREA LA CONFERINT,A DE PACE DE LA FINALUL PRIMULUI RĂZBOI MONDIAL
}

The Journal of Alexandru Lapedatu's Trip to Paris (December 1918)

\begin{abstract}
The text below is the first published edition of Alexandru Lapedatu's notes during his trip to Paris in December 1918. Lapedatu, the Secretary of the Commission of Historical Monuments, had authored several memoranda on Romania's aims at the coming peace congress, and immediately after Germany's capitulation he was appointed a councillor to the Romanian Legation to Paris. In December 1918 Lapedatu left Bucharest together with a group that accompanied Prince Nicolae (on his way to Eton), and Lapedatu took daily notes of his voyage. His journal captures his desire to get relevant information about the political situation of Europe and his struggle to contribute to the coordination of different national groups that acted to secure Romania's interests at the coming Paris Peace Congress.

Keywords: Paris Peace Congress, Europe, First World War, Romania, Alexandru Lapedatu, travel account

\section{Introducere}

Anul 1918 a dat Europei o nouă formă politică ce dăinuie, cu puține modificări, până astăzi. Pe 8 ianuarie 1918, Woodrow Wilson, președintele S.U.A., a formulat cele 14 Puncte, afirmând prioritatea criteriului demografic în viitoarele tratative, ceea ce a favorizat dezmembrarea Imperiului Austro-Ungar și a contribuit, între altele, și la crearea României Mari. Conflictul s-a încheiat înainte de sfârșitul anului $1918 \mathrm{cu}$ victoria Antantei. Pe frontul de est au avut loc evenimente esențiale pentru România [1]:
\end{abstract}

\footnotetext{
* Manuscris prefaţat, transcris şi adnotat de Johanna Wild şi Andreas Wild - Fundaţia Lapedatu (www.lapedatu.com); revizuit și comentat de Constantin Ardeleanu (Universitatea Dunărea de Jos, Galați, ardons@gmail.com).
} 
pe 3 martie, Rusia a semnat Tratatul de Pace de la Brest-Litovsk, izolând România de aliații ei occidentali și punând-o într-o situație militară de nesusţinut;

pe 5 martie, România, pe de o parte, și Germania, Austro-Ungaria, Bulgaria şi Turcia, pe de alta, au semnat Tratatul preliminar de pace de la Buftea, finalizat pe 7 mai 1918 prin Tratatul de Pace de la București (care însă nu a fost ratificat și nici promulgat de către Regele Ferdinand);

pe 10 noiembrie, România a denunțat Tratatul de la București, a reintrat în război de partea Aliaților și a trimis guvernatorului militar general al României, generalului August von Mackensen, un ultimatum pentru retragerea trupelor sale din România, executabil în 24 de ore;

Mondial.

pe 11 noiembrie, capitularea Germaniei a pus capăt Primului Război

În această perioadă, tânărul istoric Alexandru Lapedatu, secretar al Comisiunii Monumentelor Istorice, se afla la Iași. Revenise în capitala Moldovei la începutul anului 1918, după ce acompaniase al doilea transfer al tezaurului României la Moscova și obținuse din partea oficialităților acreditarea proaspăt înființatului „Comitet al refugiaților români din Austro-Ungaria” pe lângă Alianța Naționalităților din Austro-Ungaria, lansată la Kiev de Thomas G. Masaryk. [2] Prăbuşirea frontului de est a compromis însă proiectul lui Masaryk. Alexandru Lapedatu, anticipând apropierea rapidă a victoriei Antantei, s-a ocupat în vara anului 1918 de elaborarea unui memoriu comprehensiv care să argumenteze poziţia României la viitoarele tratative de pace, pe care 1-a și propus lui Ion I. C. Brătianu. A doua zi după capitularea Germaniei, Lapedatu a fost numit Consilier Referent pe lângă Legațiunea Regală a României la Paris și a primit un pașaport diplomatic (Fig. 1). Tânărul istoric a fost inclus în delegația română pentru tratativele de pace (Fig. 2). Spiritul de anticipare și urgența acțiunii autorităților române sunt remarcabile: la acel moment, statutul României ca stat aliat era nedecis, reproșându-i-se semnarea Tratatului de la București.

Înainte de plecarea de la Iași, Alexandru Lapedatu a fost primit în audiență de Rege și a vizitat mai multe personalități, primind de la Ion I. C. Brătianu misiunea de a insista pe lângă Vasile Lucaciu și Octavian Goga să nu renunțe la revendicarea integrală a Banatului. La București, Lapedatu și-a revăzut familia prima dată după doi ani; a asistat apoi la revenirea triumfală în Capitală a Regelui, Reginei și a Generalului Berthelot; după sosirea guvernului din exilul ieșean, Lapedatu și-a putut începe călătoria spre Paris, împreună cu grupul Principelui Nicolae care pleca la studii la Eton, în Regatul Unit. [3]

Călătoria sa a fost descrisă în jurnalul pe care Alexandru Lapedatu 1-a ținut în decembrie 1918. Manuscrisul său, descoperit de curând între documentele rămase 
în păstrarea descendenților, se află acum în Fondul Lapedatu de la Muzeul Național de Istorie a Transilvaniei din Cluj-Napoca. Mai jos este transcrierea documentului, inedit până acum, descriind traseul ocolitor urmat, căci rutele mai directe prin Europa Centrală erau încă inaccesibile din cauza mișcărilor de trupe în retragere (Fig. 3).

Din nefericire, prima pagină a manuscrisului a fost pierdută, dar începutul călătoriei poate fi descris reluând paragrafele respective din volumul de amintiri al lui Alexandru Lapedatu: „Acum, după sosirea guvernului, avea să se facă și plecarea mea. În ziua stabilită, am mers dis-dedimineață, mai întâi la Capșa unde locuia ministrul Mișu ${ }^{1}$ și de acolo, împreună cu acesta și însoțitorii săi, ne-am dus la Cotroceni, să luăm pe principele Nicolae. Nu se luminase bine de ziuă când am plecat de aci, cu automobilele - calea ferată nefiind circulabilă - la Giurgiu. Regele cu principele Nicolae, N. Mișu cu însoțitorii săi - avocat Rosenthal, bancherul Crisoveloni și tânărul George Asan - iar eu cu colonelul Ţonescu, adjutant regal. De la Giurgiu am trecut, numai noi, călătorii, la Rusciuc unde ne aştepta un tren special care avea să ne ducă la Constantinopol: un vagon de dormit, un vagon restaurant și un pak-vagon pentru bagaje". [4]

De altfel, comparând textul Jurnalului de mai jos cu cel al Amintirilor putem constata că însemnările de călătorie ale lui Alexandru Lapedatu au stat la baza selecției de mai apoi. Jurnalul este însă mult mai detaliat și, din perspectiva ilustrării imaginii unui continent complet zdruncinat la finalul Marelui Război, mai interesant. Notițele de călătorie surprind extrem de clar tensiunea, așteptarea, dorința de a obține informații relevante, refacerea legăturilor cu diferite centre ale mișcării naționale și încercarea de a coordona acțiunile acestor nuclee pentru a maximiza rezultatele dorite de la viitoarea Conferință de Pace.

Traversarea unor orașe cu o bogată moștenire istorică prilejuiește și mici escapade turistice, făcute însă fără „dispoziție sufletească”. La bordul vaporului britanic cu care grupul românesc și cel rusesc au părăsit Istanbul, Lapedatu are răstimpul să mediteze la aspecte naționale și la „europenitatea” românilor din mijlocul unui colectiv de patrioți extrem de divers. Atenția grupului se concentrează de-a lungul întregii călătorii spre marile evenimente care se pregăteau în capitala Franței. Mereu în căutarea ultimelor știri, citind înfocat despre descrierea intrării și

\footnotetext{
${ }^{1}$ Nicolae Mișu (1858-1924): politician și diplomat român, reprezentant al României în Bulgaria, apoi trimis extraordinar și ministru plenipotențiar al României la Viena (noiembrie 1908 - octombrie 1911), Constantinopol (octombrie 1911 - decembrie 1912) și Londra (decembrie 1912 - octombrie 1921); ministru de externe (15 octombrie - 30 noiembrie 1919 în Guvernul Artur Văitoianu), semnatar din partea României al Tratatului de Pace de la Saint Germain en Laye; administrator al Domeniilor Coroanei (1919-1920), ministru al Palatului, apoi șef al Curții Regale (1920-1924).
} 
primirii lui Wilson la Paris, Lapedatu își coordonează acțiunile cu confrații români. La Roma Vasile Lucaciu îl pune la curent cu cele petrecute în Italia și Franța cu Consiliile Naționale. Simion Mândrescu îi povestește despre activităţile sale naționale din Peninsula Italică, deși ,prin preocupările sale personale a provocat însă neînțelegeri, disensiuni”. Urmează apoi drumul spre Paris, conștient că în multe dintre chestiunile pendinte era nevoie de o mai bună coordonare a tuturor forțelor naţionale.

\section{Jurnalul călătoriei}

[Luni, 9 Decemvrie] ...

... prin Târnovo. La 4 1/2 suntem la Gorna-Orahovița ${ }^{2}$. Imi trec timpul cetind. Totuși vreo tristețe mă stăpânește - despărțirea prea repede de ai mei.

Marti 10 Decemvrie. O noapte de completă restaurare. Dimineaţa ne-am pomenit în Turcia. Trecusem chiar de Adrianopol ${ }^{3}$. Am mers așadar f. repede. La 3 $1 / 2$ vom fi la Constantinopol ${ }^{4}$, îmi spune funcționarul turc care a înlocuit pe cel bulgar la frontieră, ca inspector al vagonului nostru. La 11 suntem la Cerchezekioi ${ }^{5}$ unde comandantul englez al gării scoate garda pentru a da onorul Prințului ${ }^{6}$. Ne apropiem de Constantinopol. Am trecut de Ceatalgea ${ }^{7}$. Cald, senin, frumos - se vede că marea e'n vecinătate. La 4 am ajuns la Constantinopol. Un ofițer turc a urat bună venire Prințului în numele Comandantului pieței, iar ofițeri francezi ne-au pus la dispoziție automobile să mergem la Pera-Palace, căci, contrar așteptărilor noastre, nu avem chiar astă seară, vapor la dispoziţie. Dl Mișu s'a dus să aranajeze plecarea. Am profitat de ocazie să caut să văd orașul, adică Grande rue de Péra ${ }^{8}$. Ploaia și lipsa de lumină m'au făcut să mă întorc însă îndată la hotel. Cu toate că sunt 12 ani de când am văzut Constantinopolul, totuși, în drumul de la gară la hotel, mi-a fost aproape totul cunoscut. M-au impresionat mult, ca și odinioară, zidurile vechilor întărituri bizantine și turcești ale oraşului, care se văd bine la apropierea și intrarea trenului în gară. Din gazetele franceze locale, văd că doi delegați ai Consiliului național român din Tr.[ansilvania] au trecut prin Berna la Paris. Cine-or fi ei? Seara am cinat cu toții împreună cu Prințul. Ne neliniștește puțin faptul că autoritățile militare aliate n'au cunoștință de plecarea noastră mai departe și că, în consecință, n'au luat măsuri

\footnotetext{
${ }^{2}$ Gorna-Oreahovița.

${ }^{3}$ Edirne.

${ }^{4}$ Istanbul.

${ }^{5}$ Çerkezköy.

${ }^{6}$ Principele Nicolae al României (alternativ Nicolae Brana; 3 august 1903 - 9 iunie 1978): al doilea fiu al Regelui Ferdinand I și al Reginei Maria, fratele mai mic al Regelui Carol al IIlea și unchi al Regelui Mihai I al României.

${ }^{7}$ Çatalca.

${ }^{8}$ Astăzi İstiklâl Caddesi, Bulevardul Independenței.
} 
pentru aceasta. Pe de altă parte nu e nici un vapor disponibil cu care să putem pleca. Nespus de rău ar fi să fiu silit a sta aici câteva zile.

Miercuri 11 Decemvrie. - Înainte de amiază am făcut o primblare pe Grande rue de Péra și jos, în Galata, la port. Ce cald, ce bine, ce frumos! Păcat numai că n'am nici o dispoziție sufletească. Nu știu de ce Mișu e extrem de rece față de mine. Să-1 fi jignit cu ceva? Să fie alte cause, independente de mine? Nu-mi pot da seama. După masă am făcut o primblare spre palatul dela Dolma-Bagce ${ }^{9}$ pe unde se poate avea una din cele mai frumoase priveliști asupra Constantinopolului. Întors la hotel, pe la 5, aflu cu mulțumire că peste o oră plecăm cu un vas englezesc la Mudros (Lemnos) şi de acolo la Tarento în Italia. Mi-am făcut bagajele în grabă, am scris câteva rânduri acasă. La 7 eram pe cheiul de la Dolma-Bagce. Ne-am îmbarcat iute și am plecat. Obosit de multa preumblare de peste zi, după masă m'am retras îndată în cabină, să mă odihnesc. Sper să pot chiar dormi. Marea e calmă și vasul foarte liniștit.

Joi 12 Decemvrie. - Azi dimineață la 7 am ajuns la Galipoli, unde am stat câteva ore pentru îmbarcarea unor ofițeri englezi. Pe vasul nostru - se cheamă „Heroic" - e și delegația politică rusă care a fost la Iași în frunte cu Miliucov, Sebeco, Gorco etc. La dejun observ pe ofițerii englezi urcaţi pe vapor la Galipoli. Toți aproape - vre-o 20 - același tip caracteristic: bine făcuți și legați, sănătoși și voinici, svelți, uscați roșcovi la figură, trăsături regulate. Se cunoaște rasa. Mă uit și la noi, la „Românii” și la Rușii de alăturea. Noi, nici unul la fel cu celălalt. Cam tot așa Rușii, între ei însă $2-3$ au evident tipul slav. De altminteri trebuie să notez de altminterea că „noi” suntem foarte diferiți. Iată - Cretzeanu, Assan, Capșa, Rosenthal, Chrisoveloni, Irimescu și eu.

Vineri 13 Decemvrie. - Aseară la 6 am ajuns la Mudros (Lemnos) unde am rămas peste noapte ca să putem lua cărbuni și descărca mărfurile. Neputând dormi bine, m'am sculat dis de dimineața și am ieșit pe bord. Baia Mudrosului foarte frumoasă: largă, mărginită la orizont de munți pietroși și presărați, în margini, de multe și mărunte aşezări de sate. În toate părțile mici așezări omenești - sate.

Soarele a ieșit târziu, după șapte. Un neuitat spectacol. - Înainte de prânz am fost pe insulă, nu în Mudros, căci era închis din cauza gripei, ci într-un alt sat - căci sat e și Mudros - numit Romanos ${ }^{10}$. Am făcut un ceas la dus şi unul la întors. Vremea minunată - senin, soare, cald nespus [de] frumos în tot cuprinsul ochiului. De remarcat lucrările amiralității engleze - şosele petruite, locuințe construite, curățenie și ordine peste tot unde desigur înainte nu era decât murdărie și primitivitate. Asemenea Câmpul de aviație, cu școală pregătitoare pentru toată

\footnotetext{
${ }^{9}$ Dolmabahçe Sarayi.

${ }^{10}$ Romanou.
} 
armata de orient. Au fost și Rușii în ac. primblare. În satul grecesc Romanos nimic interesant. Case de piatră dau un aspect sumbru, trist satului. Biserica, o mizerie cum nici în ultimul sat românesc nu se află - nu ca clădire și aspect exterior ci ca rânduială și curățenie în interior. De prânz ne-am întors pe bord. Se zice că deseară plecăm spre Pireu. Un după amiază splendid, ca într-o frumoasă zi de Mai de la noi. Mai tot timpul pe coverta vaporului. Prinţul și cu cei dintre noi cari nu fuseseră înainte de amiazi pe insulă s-au dus să vadă și dânșii câmpul de aviație englez. Maiorul (Comandorul) Irimescu a și făcut un zbor c'un hidroaeroplan.

Sâmbătă 14 Decemvrie. - Aseară, la opt, am plecat de la Mudros. Acum suntem în drum spre Pireu, unde se zice că vom ajunge la ora 11. Vremea s-a stricat. Nour și puțină ploaie. Barometrul s'a coborât mult. Totuși până acum vremea continuă a fi destul de calmă și călătoria noastră tot așa de liniștită. Sunt a patra zi pe vapor. Viața aceasta e interesantă. Mai întâi nu simți oboseala, ca în călătorii cu trenul. Afară de noi Românii și de delegația rusă, nu mai e nici un civil pe vas. Tot ofițeri și marinari englezi. Îi observ de aproape. Toți serioși și liniștiți. Nici expansiunea, nici graba raselor latine. Fiecare la postul și la datoria lui. I-am văzut și la lucru - tot așa. Trăesc bine. Mănâncă și beau tot ce li se dă și mai toți fumează. Dimineața îndeosebi se ospătează mai mult ca noi, Europenii. Slănină prăjită, un fel de mâncare chemată „poreci”"11 - ceai, cafea, unt, marmeladă etc.

La 10 am ajuns la Pireu, iar la 1 am plecat mai departe spre Canalul de Corint. Între timp am coborât și [la] Pireu și am vizitat portul și orașul. Portul nu face deosebită impresie. Orașul însă da. Străzi drepte, frumoase, bine'ntreținute. Clădiri mari, magazine pline cu de toate și relativ eftin. Se cunoaște că războiul n'a golit și desorganizat, prin izolare, totul ca la noi. Moneta grecească are curs mai bun decât cea franceză bunăoară: cu $10 \%$ mai scumpă. Între $31 / 2-4$ am trecut canalul de Corint și am intrat în golful de Lepanto. Canalul e lat de vreo 25 - $30 \mathrm{~m}$ și lung de vreo $2-2 \frac{1}{2} \mathrm{~km}$. E o lucrare tehnică remarcabilă. Totuși Irimescu spune că pe lângă ceea ce au făcut Nemții la Kiel, acesta este un ,jeu d'enfant'. Aceeași greșeală de concepție ca și la podul nostru de la Cernavodă. Încă odată mai lat să fi fost, ar fi putut deservi cele mai mari vase - chiar chiurasatele de război. Seara, după masă, am stat mai mult în sala de mâncare, am cetit ziare, am discutat. Curios, par'că pierdusem sentimentul locului. Mi se părea că sunt undeva într'un restaurant sau cafenea și aşteptam să mergem... acasă.

Duminică 15 Decemvrie. - De la Pireu mergem într'una. Până la Tarent nu ne mai oprim. Suntem pe marea Ionică. Aseară era calmă. Azi dimineață destul de mânioasă. Am cercat să mă scol. Am izbutit chiar să mă spăl și să mă îmbrac. Dar atâta. Căci a trebuit să mă întind în pat și să stau liniștit. Altfel nu mergea. Cătră 11

${ }^{11}$ Porredge, terci de ovăz. 
valurile s'au potolit și vasul s'a liniștit. Un cer splendid, cum n'am văzut încă. Păcat însă că vântul mă împiedică să simt plăcerea lui de pe bord sau de pe covertă. Numai după masă valurile s'au potolit și vântul s'a mai liniștit, ca să putem privi de pe bord frumoasa intrare în portul Tarento, Taranto cum zic Italienii, unde am ajuns pe la 4. De la curățenia și liniștea de pe mare, la murdăria și agitația de pe uscat. Pare că te enervează mai ales lumea aceasta italiană de sud, expansivă, ca și a noastră. Birjarii mână nebunește, hamalii se încârduesc, copiii se țin lanț după tine. Dar ceea ce observ e că până la urcarea în tren, toate formalitățile de călătorie sunt făcute în engleză. Par'că nici n'ar fi pe aci autoritate italiană. Soldați și ofițeri italieni destui, dar numai ca călători... La ora $6 \frac{1}{2}$ am plecat, prin via Foggia, la Roma, unde vom fi mâine la 11.

Luni 16 Decemvrie. - Am dormit destul de bine. M-am sculat însă de dimineață să văd „Italia” din fuga trenului. Ziarele pe care le găsesc răspândite pe culoarul vagonului mă tentează însă mai mult. Așa că mă apuc de citit știrile, descrierea intrării și primirii lui Wilson la Paris. În urmă stau tot la fereastra vagonului. Apeninii se văd la orizont, limitând șesul lucrat peste tot. Ne apropiem de Roma. La intrarea în oraș se văd apeductele romane. La 12 suntem în Cetatea eternă. E vorba să ne despărțim: eu să rămân o zi, să pot vorbi cu Păr. Lucaciu. Am mers la Grand Hotel. După masă, luată la restaurantul Colona, mai puțin faimoasă decât mi se spusese, dau o raită prin oraș. Din Piazza Colona, în Forul lui Trajan, să văd Columna; de aici în Forul cel mare, apoi la Coliseu și sus, pe Ianicul ${ }^{12}$ spre a vedea Roma în panoramă și frumoasa, clasica statuă a lui Garibaldi. In fine la San Pietro. Înainte de masă o preumblare pe Via nazionale, iar după masă la gară să salut, de plecare, pe Prinţul Nicolae și pe ceilalți. În urmă la hotel la Păr. Lucaciu ${ }^{13}$ - care m'a pus în curent cu ce s'a petrecut la Paris și la Roma cu Consiliile Naționale. Ne-am dat întâlnire mâine la 12, la Legație.

Marti 17 Decemvrie. - Înainte de prânz, l-am vizitat pe Mândrescu ${ }^{14}$, la Hotel Imperial. Tot cel vechiu. De-un personalism patologic. Se vede întâi pe dânsul, apoi chestiunile în care s'amestecă. Nu se poate zice că n'a lucrat ceva în Italia. S'a interesat de constituirea Corpului de voluntari români, a aranjat

\footnotetext{
${ }^{12}$ Gianicolo, Ianiculum în latină.

${ }^{13}$ Părintele Vasile Lucaciu (21 ianuarie 1852 - 29 noiembrie 1922): preot greco-catolic cu doctorat la Roma, inițiator și semnatar al Memorandumului, lider al Partidului Național Român, parlamentar.

${ }^{14}$ Simion Mândrescu (18 iulie 1868 - 30 septembrie 1947): profesor universitar, titular al primei catedre de Limba si literatura germana la Universitatea din București, membru al grupului plecat în 1917-1918 pentru a face propagandă în numele „Asociației profesorilor universitari” în Franța, apoi în Italia; la 15 octombrie obține acordul guvernului italian pentru înființarea „Legiunii Românești” constituită din prizonierii români din armata austro-ungară aflați în Italia, care să lupte alături de trupele italiene.
} 
meetinguri la Roma și Milano pentru causa noastră, a acordat interviewuri, a dat telegrame etc. A agitat în fine lumea italiană pentru chestia română. Prin preocupările sale personale a provocat însă neînțelegeri, disensiuni, cari au luat forme destul de păgubitoare atât pentru susținerea causei noastre cât și pentru prestigiul nostru. La amiazi am văzut la Legație pe Ministrul Lahovary ${ }^{15}$, pe Col. Florescu, pe Prințul Wlad. Ghica ${ }^{16}$, pe Păr. Lucaciu și - cu plăcere - pe poetul nostru Cotruș ${ }^{17}$. Prânzul ni 1-a oferit câțiva Italieni din România (Ing. Fantoli, Deluca, Tomaselli, Gronda etc.) la Castelo deli Caesari, între ruinele vechei Rome. Ne-am simțit foarte bine în mijlocul expansivității italiene. Prin ei am putut lua cunoștință de starea de spirit a Italienilor. C'o conștiență exagerată de rolul pe care l-au avut în războiu și de importanța lor politică, manifestă o foarte pronunțată dispoziție împotriva Francezilor, între altele şi pentru că nu-i susțin în revendicările lor la Adriatica împotriva Serbilor. Dealtfel conflictul cu Jugo-Slavii a luat proporții violente. Nu numai polemici vii prin presă, dar chiar și conflicte directe, cum a fost la Fiume. Caracteristic că nu înțeleg să cedeze întru nimic, ca noi în chestia Banatului, cu toate că nu pot invoca atâtea drepturi ca noi aci. După masă, în drum la hotel m-am oprit la o abație să vizităm pe Pres. episcop din Iași, Cipolini ${ }^{18}$, de curând sosit din Moldova. La hotelul „Minerva” am avut o întrevedere mai lungă cu Wlad. Ghica - și el e foarte sceptic și foarte timid, ca atitudine, în chestiunea Banatului. Are legături bune cu Ceho-Slovacii (Beneș ${ }^{19}$, Stefanek $^{20}$ şi Massarik ${ }^{21}$ ) și cu Polonii. La cei dintâi zice că s'ar fi înțeles ce privește Maramureșul și com.[itatele] rutene, să se împartă între Slovaci și Români întrucât Rutenii nu vor

\footnotetext{
${ }^{15}$ Alexandru Em. Lahovary (1855-1950): diplomat, Ministru al României la Constantinopol, Viena, Paris şi Roma (2 decembrie 1917 - 1 februarie 1928).

${ }^{16}$ Monseniorul Vladimir Ghika (25 decembrie 1873 - 16 mai 1954): print, diplomat, scriitor, om de caritate, preot catolic român (biritual: latin şi bizantin), beatificat pe data de 31 august 2013 la București.

${ }^{17}$ Aron Cotruș (2 ianuarie 1891 - 1 noiembrie 1961): diplomat și scriitor român.

${ }^{18}$ Pr. Ulderic Cipolloni (10 mai 1868 - 3 aprilie 1927): preot italian, rector al Seminarul Franciscan din Hălăuceşti, numit la 30 ianuarie 1916 administrator apostolic al diecezei Iaşi. A mai fost apoi paroh la Huși și la Galați.

19 Edvard Beneš (28 mai 1884 - 3 septembrie 1948): om politic ceh, președinte al Cehoslovaciei (1935-1938 și 1939-1948), ministru al afacerilor externe (1918-1935), primministru al Cehoslovaciei (1921-1922) și președinte al Cehoslovaciei în exil (1939-1945).

${ }^{20}$ Milan Rastislav Štefánik (21 iulie $1880-4$ mai 1919): astronom, politician şi general slovac, unul dintre cofondatorii Republicii Cehoslovace.

${ }^{21}$ Tomáš Garrigue Masaryk (7 martie 1850 - 14 septembrie 1937): filozof, sociolog și om politic cehoslovac, care a militat pentru independența Cehoslovaciei în timpul Primului Război Mondial și a devenit fondatorul și primul președinte al Cehoslovaciei.
} 
trece, cu Statul lor, dincoace de Carpați. De Fasciotti ${ }^{22}$ mi-a spus, ceea ce știam de altfel, că nu ne e prieten, că e bulgarofil și chiar maghiarofil, că stă rău la Consulta ${ }^{23}$, dar că totuși rapoartele lui acolo ne pot face destul rău. Ghica mi-a promis că va servi în presa italiană causa noastră prin cele ce vom trimite acolo. Întors la hotel am făcut pregătiri de plecare. La 9 1/2 eram în tren spre Modane ${ }^{24}$.

Miercuri 18 Decemvrie. - Am călătorit destul de bine. La 10 1/2 - 11 eram la Genua iar la 3 1⁄2 - 4 la Turin. Seara la 7 1/2 la Modane.

Joi 19 Decemvrie. La 11 1/2 am ajuns la Paris. Ploaie și vânt. Am umblat mult până am găsit o odaie la hotelul rezervat misiunilor străine, Eduard VII. După masa pe Place de la Concorde am văzut cortegiul primirii Regelui Italiei. Apoi am fost la Legație. Câteva cuvinte numai cu Ministrul Antonescu. Am mai văzut apoi pe rând, pe Tellia, pe $\mathrm{Goga}^{25}$ și pe $\mathrm{Bocu}^{26}$. Goga plin de grandomanie. A cedat și el, cu Take Ionescu ${ }^{27}$ și mai toți, în chestiunea Banatului față de Sârbi. Singur Bocu s-a opus și a izbutit să facă un contra curent în ac. privință. Lucrează chiar la o broșură reprezentând punctul de vedere românesc în chestiunea Banatului.

Vineri 20 Decemvrie. - O zi, aș putea zice, de liniște. De dimineața în Louvre $^{28}$ pentru cumpărături. După masă la Seceleanu ${ }^{29}$, iar seara, cu Goga și Lupu $^{30}$, la masă.

\section{Încheiere}

\footnotetext{
${ }^{22}$ Carlo Fasciotti (28 decembrie 1870 - 7 august 1958): diplomat italian, trimis extraordinar și ministru plenipotențiar, regentul Legației italiane la București din iunie 1911 până în august 1919.

${ }^{23}$ Palazzo della Consulta, unde a funcționat între 1874 și 1922 Ministerul Afacerilor Externe al Italiei.

${ }^{24}$ Trecerea între Italia și Franța se face prin tunelul feroviar Fréjus (numit și tunelul MontCenis) dintre Bardonnechia (Italia) și Modane (Franța).

${ }^{25}$ Octavian Goga (1 aprilie 1881 - 7 mai 1938): poet, politician, ministru și președinte al Consiliului de miniștri (28 decembrie 1937 - 11 februarie 1938), membru al Academiei Române din anul 1920.

${ }^{26}$ Sever Bocu (19 noiembrie 1874 - 21 ianuarie 1951): politician român, economist, ziarist, deputat, ministru.

27 Take Ionescu (13/25 octombrie 1858 - 2 iunie 1922): om politic, avocat și ziarist român, ministru al instrucțiunii publice și cultelor, de finanțe, de externe și președinte al Consiliului de Miniștri (1921-1922).

${ }^{28}$ Desigur, „Grands magasins du Louvre” aflate în Place du Palais Royal în apropierea hotelului „Eduard VII”.

${ }^{29}$ Probabil, N. N. Seceleanu, co-semnatar al unei moțiuni a „Adunării generale a românilor din Franța" din 6 septembrie 1918, fratele lui D. N. Seceleanu, mare agricultor în Bărăgan, senator în 1918.

${ }^{30}$ Dr. Nicolae Lupu (4 noiembrie 1876 - 1947): medic, politician român, membru în Partidul Țărănesc, ministru.
} 
La Paris, Alexandru Lapedatu a fost un membru activ al delegației, scriind mai multe memorii prezentate de delegația română, dezvoltând conceptul hărților demografice utilizate în argumentație și participând la ceremonia semnării Tratatului de la Versailles. [5] Întors în țară, a devenit un membru important al Partidului Național Liberal, de mai multe ori ministru, președinte al Senatului Român şi senator de drept, fără a-și neglija viața profesională ca profesor la Universitatea Română din Cluj, secretar și președinte al Academiei Române și președinte al Comisiunii Monumentelor Istorice. Contribuțiile sale în aceste funcții îl confirmă drept unul dintre ctitorii României moderne în perioada interbelică.

\section{Referințe}

1. Kiritzesco, Constantin, La Roumanie dans la Guerre Mondiale, Payot, Paris, 1934.

2. Lapedatu, Alexandru, „Mr. De Saint-Aulaire et les roumains réfugiés d'Autriche-Hongrie pendent la Grande Guerre", în: Hommage à Mr. De Saint-Aulaire, Imprimerie SOCEC \& Co., Bucarest, 1930, p. 51-65.

3. Alex. Lapedatu, Amintiri (prefață, ediție îngrijită, note și comentarii de Ioan Opriş), ediţia pe hârtie: Editura Albastră, Cluj-Napoca, 1998; ediția Internet: Fundaţia Academia Civică 2015 (http://www.memorialsighet.ro/carti/alexandru-lapedatu-amintiri-2/), p. 170.

4. Ibidem, p. 174.

5. ***, La Roumanie devant le Congrès de la Paix, Ed. Dubois et Bauer, Paris, 1919. 


\section{Ilustrații}

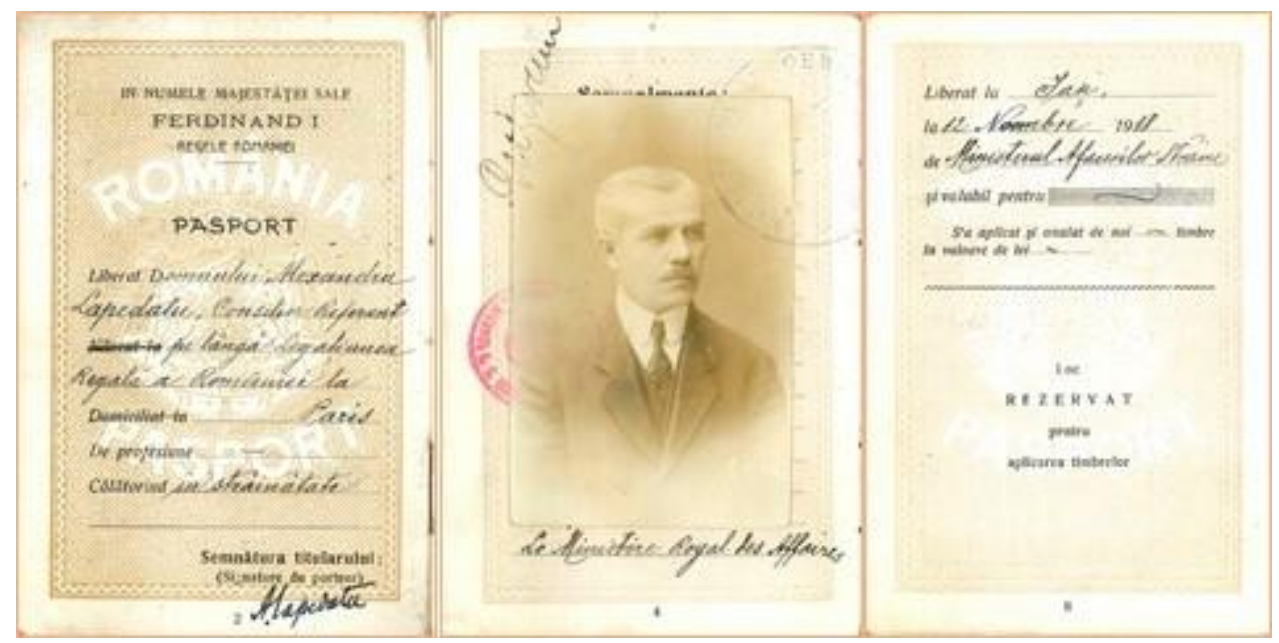

Fig. 1

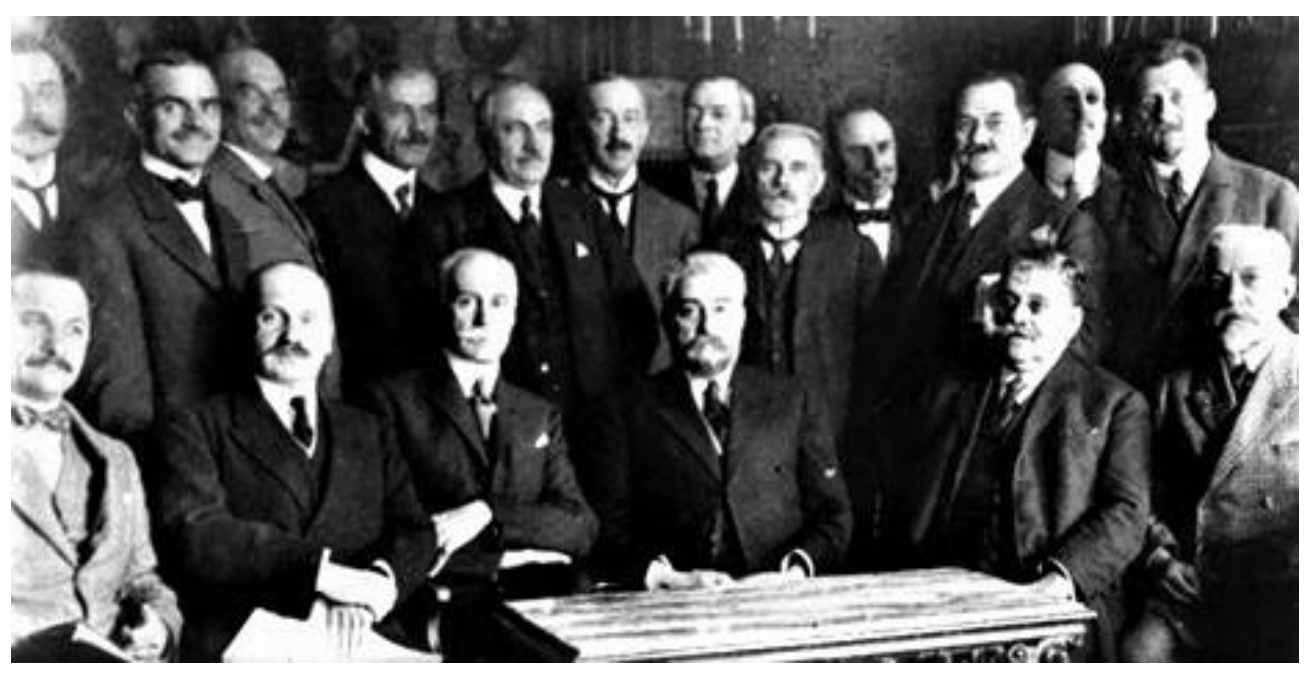

Fig. 2 


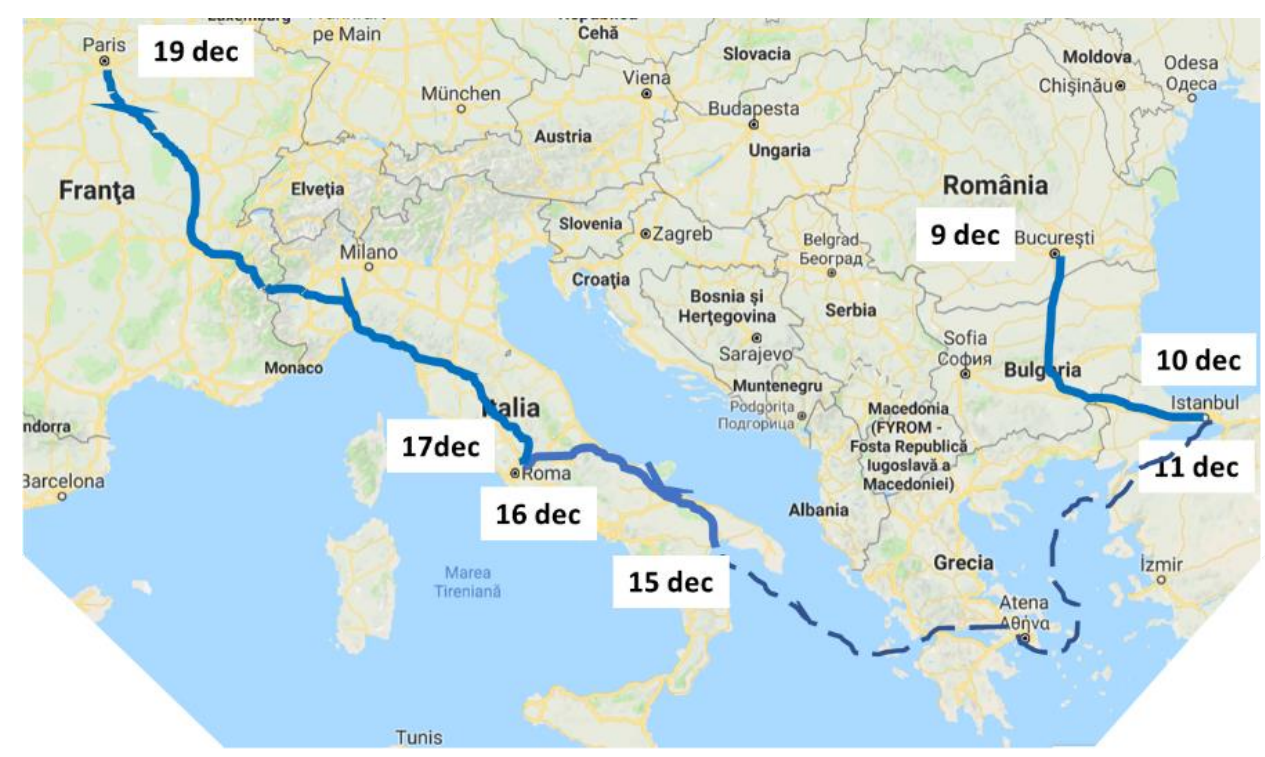

Fig. 3

\section{Explicația ilustrațiilor}

Fig. 1. Pașaportul diplomatic acordat lui Alexandru Lapedatu pe 12 noiembrie 1918

Fig. 2. Delegația română la Conferința de pace de la Paris în 1919; Alexandru Lapedatu este în picioare, al patrulea din stânga

Fig. 3. Traseul urmat de Alexandru Lapedatu de la București la Paris în decembrie 1918 